\title{
First PATTEC consultative workshop on strategies, technical advances and partnerships in tsetse and trypanosomosis management
}

\author{
Hassane H. Mahamat*
}

\section{Keywords}

Glossina, African trypanosomosis, disease control, partnership

Submitted: February 2, 2015; Accepted: March 31, 2015; Published: November 20, 2015

\section{Summary}

Tsetse and trypanosomiasis (T\&T) remain endemic in many countries, although many efforts have been made in recent decades within the framework of the Pan-African Tsetse and Trypanosomiasis Eradication Campaign (PATTEC) Initiative, and despite progress observed both in research and development, and in the commitment of many partners to support control efforts. In order to create a functional multipartite platform to control T\&T, a consultative workshop involving all stakeholders was held in 2014. In conclusion of the workshop, the competence and multidisciplinary of the various partners was acknowledged, as well as the need for progress in areas such as the revision of chemoprophylaxis and treatment strategies with regard animal trypanosomoses, the application of human African trypanosomiasis surveillance strategies, and the need to understand better the mechanism of resistance to trypanocides and the factors that maintain trypanosomiasis without tsetse transmission. The need to centralize the results of operational research to improve policy formulation and management techniques was also discussed. Geographic information systems were acknowledged as planning and management tools to control T\&T. This first consultation workshop ended with a plea for better communication and a clear definition of roles as a guarantee of success of an effective partnership.

- How to cite this article: Mahamat H.H., 2015. First PATTEC consultative workshop on strategies, technical advances and partnerships in tsetse and trypanosomosis management. Rev. Elev. Med. Vet. Pays Trop., 68 (1): $45-47$
$\mathrm{I}$ n spite of numerous efforts made over the past decades to address the tsetse and trypanosomiasis (T\&T) challenge on the African continent, the problem is still very much present in many T\&T affected countries. This is in contrast to the fact that there has been recent technical advances in the field of tsetse control and trypanosomiasis management, which should translate into more effective programs in the future with the commitment of policy makers and technical personnel. The aerial spraying operations

* African Union Commission, Roosevelt Street, PO Box 3243, Addis Ababa, Ethiopia. E-mail: hassanehm@africa-union.org in Botswana (Kgori et al., 2006), which greatly benefited from the Global Positioning System (GPS) technology and its associated Geographical Information System (GIS), and recent developments in remote sensing, population genetics, sterile insect technique, bait technology, T\&T surveillance, diagnoses and management, are good examples of such advances.

In addition, although networks which focus on various aspects of the T\&T domain exist, opportunities to bring together their vast knowledge are often lacking. Some T\&T forums and platforms can serve this purpose, but the forums in particular are held too rarely or their agendas lack focus. These networks and platforms hold the possibility to address the T\&T challenge in a collaborative approach, but it is essential to organize a functional 
multi-stakeholder partnership framework designed to guide African trypanosomosis management. The current T\&T management objectives do not adequately address the socio-economic aspects of the T\&T challenge as management programs invariably conclude understanding clearly basic tsetse ecology and trypanosomosis epidemiology, but they do not propose strategies to address socio-economic aspects such as land management after a successful tsetse eradication campaign. Furthermore, experience has shown that there is still a disconnection between, on one hand, researchers and academic institutions and, on the other hand, field implementers of T\&T interventions.

In response to this situation, a workshop was designed to bring together various partners/stakeholders and field implementers. It aims to share practical knowledge, information and experiences on new technologies and strategies related to T\&T, and to make recommendations that will enable affected countries to achieve their main objectives of reducing T\&T burden and create T\&Tfree areas for sustainable agricultural activities. The workshop was attended by about 60 national PATTEC coordinators and focal points from 16 African countries (Angola, Botswana, Burundi, Cameroon, Ethiopia, Ghana, Kenya, Malawi, Niger, Rwanda, Sudan, South Sudan, Tanzania, Uganda, Zambia, Zimbabwe), representatives of international organizations, research institutions, private and public partners including FAO, AVIMA CHIMTALK, VESTERGAARD FRANDSEN, ORSMOND AVIATION, BIODIVISION Foundation, GALVMED, FIND, CIRDES/LSTM, and experts from the United Kingdom, and was held in Livingstone, Zambia, from 8 to 11 September 2014.

The workshop reviewed policies, strategies and standards of tsetse and trypanosomosis / human trypanosomiasis control and eradication, T\&T management structures, by quoting as examples the Kenya Tsetse and Trypanosomiasis Eradication Council (KENTTEC), the Coordinating Office for Control of Trypanosomiasis in Uganda (COCTU), the Nigerian Institute for Trypanosomiasis Research (NITR), and the National Institute for the Control and Stakeholders also analyzed new technical advances including tiny targets, zero fly nets, new formulation insecticides and new diagnostic kits for animal trypanosomosis. Lessons learned from field operations were also examined and group discussions on a framework to guide management of tsetse and trypanosomosis intervention programs closed working sessions.

The workshop recognized the diversity and high number of competent partners and stakeholders in the T\&T domain, and the following needs were identified regarding strategies and policies of T\&T management:
- Review of strategies for chemoprophylaxis and chemotherapy of animal trypanosomosis because of treatment failures, narrow safety margins of available drugs, apparent wide spread resistance, misdiagnosis, etc.;

- Guidelines for sustainable land use management of tsetse freed areas;

- In-depth understanding of trypanocide resistance in order to formulate strategies to address it;

- In-depth understanding of factors that determine persistence and epidemiology of non-tsetse-transmitted animal trypanosomosis (NTTAT) in tsetse free areas;

- Post human-African-trypanosomosis-elimination surveillance strategies to confirm disease absence;

- Collation of T\&T operational research results to enhance evidence-based policy formulation;

- Clear definitions and consistent use of terminology relating to T\&T management;

- Clear guidelines or policy briefs on the use of T\&T control techniques (sequential aerosol technique, live bait $\&$ artificial bait systems, sterile insect technique) in the appropriate ecological or epidemiological settings;

- Adoption of standards to declare areas free of tsetse and tsetse transmitted trypanosomoses; and

- Urgent collaboration with regional economic communities to develop regional $\mathrm{T} \& \mathrm{~T}$ programs.

Recognizing the role of GIS as an essential tool for planning and managing T\&T programs, stakeholders agreed on the following:

- Call for partners to align their strategies to the African Union PATTEC roadmap for T\&T eradication;

- Call for the evaluation of the multinational projects supported by the African Development Bank to draw lessons which can inform future program formulation and implementation;

- Call for a detailed stakeholder analysis to speed up and enhance the formation of effective partnerships in T\&T management; and

- Call for an increase in donors' investments.

The first PATTEC consultative workshop concluded by issuing advocacy for better communication and clear definition of roles as key issues for effective partnerships. Their recommendations can be viewed at: www.au.int/SP/PATTEC

\section{REFERENCE}

Kgori P.M., Modo S., Torr S.J., 2006. The use of aerial spraying to eliminate tsetse from the Okavango Delta of Botswana. Acta Trop., 99 (2-3): 184-199 


\section{Résumé}

Mahamat H.H. Premier atelier consultatif sur le partenariat, les progrès techniques et les stratégies de lutte contre les mouches tsé-tsé et les trypanosomoses

Les mouches tsé-tsé et les trypanosomoses (T\&T) persistent de façon endémique dans de nombreux pays bien que de nombreux efforts aient été consentis ces dernières décennies dans le cadre de l'initiative "Campagne panafricaine d'éradication de la mouche tsé-tsé et de la trypanosomose » (Pattec), et malgré les progrès observés tant au niveau de la recherche et du développement, qu'à celui de l'engagement de nombreux partenaires pour soutenir les efforts de lutte. Dans le but de créer une plateforme multipartite fonctionnelle de lutte contre les $T \& T$, un atelier consultatif réunissant toutes les parties prenantes a été organisé du 8 au 11 septembre 2014. En conclusion de cet atelier, la compétence et la multidisciplinarité des différents partenaires ont été reconnues, mais également la nécessité de progrès dans différents domaines comme la révision des stratégies thérapeutique et chimioprophylactique pour les trypanosomoses animales, l'application de stratégies de surveillance de la trypanosomiase humaine africaine, et la nécessité d'une meilleure compréhension du mécanisme de résistance aux trypanocides et des facteurs permettant le maintien des trypanosomoses non transmises par les tsé-tsé. Le besoin de centraliser les résultats de la recherche opérationnelle afin d'améliorer la formulation des politiques et des techniques de management a également été évoqué. Les systèmes d'information géographique ont été reconnus comme des outils de planification et de gestion de la lutte contre les T\&T. Ce premier atelier de concertation s'est terminé par un plaidoyer pour une meilleure communication et une définition claire du rôle de chacun comme gage de réussite d'un partenariat efficace.

Mots-clés : Glossina, trypanosomose africaine, contrôle des maladies, partenariat

\section{Resumen}

Mahamat H.H. Primer taller consultivo PATTEC sobre estrategias, avances técnicos y asociaciones en el manejo de tsetsé y tripanosomiasis

Tsetsé y tripanosomoses (T\&T) continúan a ser endémicos en muchos países, a pesar de los muchos esfuerzos realizados en décadas recientes, dentro del cuadro de la iniciativa de Campaña Pan Africana de Erradicación de Tripanosomiasis y Tsetsé (PATTEC) y a pesar de los progresos observados, tanto en investigación como en desarrollo, y del compromiso de muchos asociados para respaldar los esfuerzos de control. Con el fin de crear una plataforma funcional multipartito para controlar T\&T, en 2014 se llevó a cabo un taller consultivo involucrando a todos los interesados. En conclusión del taller, fue reconocida la competencia y el carácter multidisciplinario de los varios afiliados, así como la necesidad para progresar en áreas como la revisión de la quimo-profilaxis y estrategias de tratamiento con respecto a la tripanosomosis animal, la aplicación de estrategias de vigilancia de la tripanosomiasis africana humana y la necesidad de entender mejor el mecanismo de resistencia a los tripanicidas y los factores que mantienen la tripanosomiasis sin transmisión tsetsé. Se discutió también la necesidad de centralizar los resultados de la investigación operacional con el fin de mejorar la formulación de políticas y técnicas de manejo. Se reconocieron los sistemas de información geográfica como herramientas de manejo y planeamiento para controlar T\&T. Este primer taller de consulta culminó con una petición de mejorar la comunicación y una definición clara de los roles como garantía de éxito de una asociación efectiva.

Palabras clave: Glossina, tripanosomosis africana, control de enfermedades, coparticipación 
